\title{
Література
}

1. Горошнікова I. Г. Модель процесу правової соціалізації дітей-сиріт підліткового віку в загальноосвітній школі-інтернаті / І. Г. Горошнікова // Збірник наукових праць БДПУ (Педагогічні науки). - Бердянськ : БДПУ, 2012. - № 3. - С. 5460. 2. Постанова Кабінету Міністрів України «Про затвердження Державної цільової програми реформування системи закладів для дітей-сиріт та дітей, позбавлених батьківського піклування»: станом на 17 жовтня 2007 року [Електроний ресурс] // Офіційний сайт Верховної Ради України.- Режим доступу : http://zakon1.rada.gov.ua/laws/show/1242-2007-п.

УДК : 37: $304-37.02 .-37.98$

Олена Смик

\section{ФОРМУВАННЯ ЗДОРОВОГО СПОСОБУ ЖИТТЯ МОЛОДШИХ ШКОЛЯРІВ ЗАСОБАМИ ІГРОВОЇ ДІЯЛЬНОСТІ}

Смик О. К. Формування здорового способу життя молодших школярів засобами ігрової діяльності.

У статті розкрито сутність понять «здоровий спосіб життя», «ігрова діяльність»; представлено результати дослідження впливу ігрових технологій на формування здорового способу життя учнів молодших класів.

Ключові слова: здоров'я, здоровий спосіб життя, гра, ігрова діяльність.

Смык О. К. Формирование здорового образа жизни младшых школьников средствами игровой деятельности.

В статье раскрыта сущность понятий «здоровый образ жизни», «игровая деятельность»; представлено результаты исследования влияния игровых технологий на формирования здорового образа жизни учеников младшых классов.

Ключевые слова: здоровье, здоровый образ жизни, игра, игровая деятельность.

Smyk O. K. Health Promoting of younger pupils by the means of playing.

The article deals with the essence of the concepts of «healthy lifestyle», «game activities»; presents results of influence of the game on a healthy lifestyle of the primary school pupils.

Key words: health, healthy lifestyle, game, gameplay activity.

На сучасному етапі виховання здорового покоління визначається як загальнодержавне завдання, важливість реалізації якого передбачено Конституцією України, законодавчими актами України у сфері охорони здоров'я, Національною доктриною розвитку освіти у XXI столітті, Державними національними програмами «Діти України» і «Планування сім’і», комплексною цільовою програмою «Фізичне виховання - здоров'я нації». Діти все частіше опиняються в зоні ризику: хворіють на застудні захворюванняи, спостерігаються різні форми сколіозу та нервових розладів. Загальне погіршення стану здоров'я дітей значно обмежує можливості засвоєння ними навчального матеріалу, що, у свою чергу, впливає на рівень інтелекту, може гальмувати в цілому суспільний розвиток. Одна 3 причин значного погіршення здоров'я школярів - недостатня проінформованість про способи збереження i зміцнення здоров'я, несформованість культури здоров'я у дітей, низька мотивація до здорового способу життя. Це засвідчує доцільність упровадження в освітньо-виховну 
систему методів ігрової діяльності, яка найбільш чітко відповідає потребам особливостям молодшого шкільного віку.

Аналіз останніх досліджень і публікацій свідчить, що проблема формування здорового способу життя дітей $є$ актуальною як у філософії та соціології, так і в педагогіці і психології. Зокрема серед дослідників окресленої проблеми можна виокремити О. Ващенка, Л. Винокур, Є. Гуріна, О. Калюжну, В. Рубанович, Д. Солопчука та інших. Дослідженню ігрової діяльності молодших школярів присвячено праці вчених Р. Вайноли, 3. Дехтяренко, В. Кузя, Н. Кудикіної, О. Леськів, О. Матвієнка, С. Мельничука, А. Фока, М. Яновської та багатьох інших.

Проаналізувавши психолого-педагогічну літературу й дисертаційні праці, у яких розкрито різні погляди на виховання і розвиток молодших школярів у процесі ігрової діяльності, можна зробити висновок, що проблемі формування здорового способу життя в учнів молодших класів засобами ігрової діяльності не приділялося достатньої уваги.

Mema cmammi - схарактеризувати основні поняття дослідження та обгрунтувати виховний потенціал ігрової діяльності у формуванні здорового способу життя молодших школярів.

Ми не будемо детально аналізувати поняття «здоров'я», а обмежимося лише узагальненими характеристиками. Переважно в довідниковій літературі здоров'я розглядають як цілісне, системне явище, що виявляється у можливості організму людини адаптуватись до змін довкілля на основі біологічної, психічної, духовної та соціальної сутності особистості. У контексті нашого дослідження ми базуємось на характеристиці здоров'я, викладеному в преамбулі Статуту Всесвітньої організації охорони здоров'я ще у 1948 р.: «Здоров’я - це такий стан людини, якому властиві не тільки відсутність хвороб або фізичних вад, але і повне фізичне, духовне та соціальне благополуччя» [4]. Спосіб життя - це система взаємовідношень людини 3 самою собою та факторами зовнішнього середовища [3, с. 12].

Отже, спираючись на нижчевикладене, ми можемо трактувати здоровий спосіб життя як все в людській діяльності, що стосується збереження і зміцнення здоров'я, все, що сприяє виконанню людиною своїх людських функцій з оздоровлення умов життя - праці, відпочинку, побуту. Т. Бойченко та Н. Колотій розуміють здоровий спосіб життя як сукупність форм життєдіяльності людини, яка забезпечує ії здоров'я та успішний життєвий шлях; С. Попов - як комплекс дій, переживань стереотипів поведінки, орієнтованих на здоров'я; Ю. Лісіцин - як діяльність, активність особистості, спрямовану на власне благополуччя та добробут суспільства $[1$, с. 8].

Практичні заходи з формування здорового способу життя найлегше реалізовувати в організовану середовищі. 3 огляду на це загальноосвітня школа, як визначальне навчально-виховне середовище, посідає особливе місце у розв'язанні цієї проблеми. Це пояснюється певними умовами: по-перше, на роки перебування у шкільному середовищі припадають найбільш сензитивні періоди формування особистості дитини 3 позиції можливостей прищеплення здорових навичок, набуття необхідних для цього знань, виховання безумовного пріоритету індивідуального і громадянського здоров'я у системі поглядів людини. По-друге, шкільним навчання охоплена переважна більшість дітей віком від 6 до 17-18 років, відповідно й заходами формування здорового способу життя можна охопити більший контингент, ніж у будь-якому іншому середовищі. По-третє, школа, - це чи не єдине в сучасних умовах вітчизняних реалій місце, де можна одночасно об'єднати процеси освіти щодо збереження здоров'я, навчання веденню здорового способу життя та виховання в напрямі здоров'я, диференціювати зміст навчально-виховного процесу щодо 
формування ЗСЖ з урахуванням вікових особливостей розвитку учнів.

Пріоритетним видом діяльності дітей молодшого шкільного віку є навчання, хоча гра досі залишається впливовим видом діяльності та є однією з форм навчання і виховання молодших школярів, що допомагає здійснити поступовий перехід від звичної для них ігрової діяльності до навчальної діяльності. Ігрова діяльність не зникає, а продовжує розвиватися, ускладнюватися. Як явище багатогранне, їі можна розглядати як особливу форму існування всіх, без винятку, сторін життєдіяльності колективу. Виховання молодших школярів під час ігор є важливою передумовою забезпечення їхнього фізичного розвитку та виховання морально-вольових якостей [2, с. 45]. За Л. Виготським, гра - це «уявна ситуація», яка створюється дорослим або самою дитиною, в якій реалізуються дитячі бажання, у якій внутрішні процеси дитини виявляються у зовнішньому вигляді і яка $\epsilon$ джерелом розвитку дитини. Д. Ельконін - гра є важливою умовою проникнення дитини в сферу соціальних взаємин, їх своєрідного моделювання в ігровій діяльності.

Наведемо приклади використання різних видів ігор для формування здорового способу життя у середовищі молодших школярів.

Рухлива гра - сама по собі є важливим засобом фізичного виховання дітей, вона завжди вимагає від тих, хто грає, активних рухливих дій, що спрямовані на досягнення умовної мети, що зазначена в правилах та сприяє фізичному розвитку гравців. Головне завдання вчителя - слідкувати, щоб усі учні були до неї залучені. Проходити може у формі естафети, ігор $з$ елементами спорту, ігрових вправ, ігоратракціонів тощо.

Серед переваг настільних ігор відзначаємо: активність всіх іiі учасників; можливість програвати різні моделі поведінки, інші ролі; можливість одержання нового соціального й особистісного досвіду у процесі гри; глибокий рівень засвоєння інформації завдяки емоційним переживанням; вироблення вміння слухати та чути інших; знання «пропускаються через себе», i деякі висновки людина робить самостійно, або під час групового обговорення; можливість у невимушеній формі та атмосфері набувати досвід. Тут варто виокремити ігри з формування ЗСЖ, розроблені спеціалістами Всеукраїнського громадського центру «Волонтер», за підтримки Дитячого фонду ООН - ЮНІСЕФ та поширені в соціальних інституціях - «Володар кілець», «Крок за кроком», «Пригоди у країні Здоровляндії». Досвід використання таких ігор у загальноосвітній школі № 5 засвідчує їх глибокий виховний потенціал.

Дидактична гра завжди має навчальну мету. Тому основним іiі компонентом $\epsilon$ дидактичне завдання, приховане від дитини в ігровому завданні. Дошкільник не просто грається, а бере участь у процесі стихійного навчання, дотримуючись при цьому усвідомлених правил. Своєрідність дидактичної гри полягає в раціональному поєднанні дидактичних та ігрових завдань. Тематикою таких ігор може бути «Знайомство з моїм організмом», «Пан вітамін», «Тренування пам’яті», «Чисті руки запорука здоров'я» та інші.

Метою інтелектуальної гри є розвиток когнітивної складової формування ЗСЖ молодших школярів. Найчастіше це варіанти телевізійних програм формату «запитання-відповідь» : «Що? Де? Коли?», «Брейн-ринг», «Найрозумніший». Вони стимулюють мислення, пам'ять, сприяють засвоєнню інформації. Запитання для таких ігор можуть бути присвячені гігієні, шкідливим звичкам, правилам етикету, спортивним досягненням українців тощо.

Сюжетно-рольова гра займає особливе місце в моральному вихованні дитини. У такій грі на основі життєвих або художніх вражень вільно і самостійно відтворюються соціальні відносини та матеріальні об’єкти або розігруються фантастичні ситуації, що 
не мають поки що аналогу в житті. Основні компоненти рольової гри - тема, зміст, уявна ситуація, сюжет та роль.

Пропонуємо ігри: «Як поводитись на перерві», «Я- пішохід», «Добрий стоматолог», «Здоровий ранок», «Служби порятунку».

Гра-драматизація подібна до сюжетно-рольової гри, різниця в тому, що дії учасників тут $\epsilon$ не спонтанними, а розігрувані зображування $\epsilon$ заздалегідь підготовленими зі збереженням послідовності епізодів. Дитина перевтілюється, входить в образ, живе життям свого персонажу. Особливо улюбленими є ігридраматизації, сюжетами яких є добре відомі учням казки, розповіді, театралізовані вистави. При цьому можуть бути використані ляльки. Сюжетом такої гри може бути реальна історія людини, яка веде нездоровий спосіб життя чи вигадана історія. Інша тематика: «В гості до пані Пігулки», «У царстві гігієни», «Суд над цигаркою», «Як Марійка здоров'я здобула».

В основі гри-бесіди знаходиться спілкування педагога $з$ дітьми, дітей 3 педагогом та дітей один з одним. Це спілкування має особливий характер ігрового навчання та ігрової діяльності дітей. Під час гри-бесіди педагог часто діє не від себе, а від близького дітям персонажа і тим самим не тільки зберігає ігрове спілкування, але й посилює радість його, бажання повторити гру. Орієнтовна тематика гри-бесіди «Як харчуватися правильно», «Комп’ютер - друг чи ворог?», «Моє безпечне літо», «Сила посмішки» та інші.

Гру-мандрівку іноді неправильно ототожнюються з екскурсією. Суттєва різниця ïх полягає в тому, що екскурсія - форма прямого навчання та різновид занять. Метою екскурсії частіше всього $є$ ознайомлення з чим-небудь, що потребує безпосереднього спостереження, порівняння 3 уже відомим. Іноді гру-мандрівку ототожнюють 3 прогулянкою. Але прогулянка частіше за все має оздоровчу мету. Пізнавальний зміст може бути і на прогулянці, але він $\epsilon$ не основним, а супроводжуючим. Завдання гримандрівки - посилити враження, надати пізнавальному змісту трошки казкової незвичності, звернути увагу дітей на те, що знаходиться поряд, але не береться ними до уваги. Ігри-мандрівки потребують кропіткої підготовки педагога. Приклади гримандрівки:

«Приховані скарби природи», «Безпека на шкільному подвір'ї».

Графічна гра передбачає використання творчого потенціалу. Подібні ігри часто застосовуються у терапевтичних цілях, дитина переносить свої внутрішні переживання в середовище шляхом використання засобів образотворчого мистецтва (малювання, ліплення, колаж тощо). Наприклад «3 чого складається здоров’я», «Що таке корисні звички?», «Активний відпочинок» тощо.

Отже, можемо зробити висновок, що ігрове навчання відрізняється від інших педагогічних технологій тим, що гра добре відома, звична та улюблена форма діяльності дітей. Гра дозволяє здійснювати на них виховний вплив, захоплювати увагу, переконувати, здійснювати терапевтичний вплив. Кожен вид ігор здатен сприяти формуванню здорового способу життя молодших школярів, тому усе залежить від бажання та готовності вчителя використувати потенціал ігрової діяльності. Перспективи подальших досліджень ми вбачаємо у створенні методичних порад учителям молодших класів щодо формування здорового способу життя молодших школярів засобами ігрової діяльності.

\section{Література}

1. Бойченко Т.В. Основи здоров'я : [експериментальний посібник для учнів] / Т. В. Бойченко, Н. М. Колотій. - К. : Державнгий інститут проблем сім’і та молоді, 
Український ін-т соціальних досліджень, 2004. - 112 с. 2. Войцях Т. В. Ігрові технології як інструмент профілактичної роботи спеціалістів психологічної служби закладів освіти: [навч.-метод. посіб.] / Т. В. Войцях. - Черкаси : Черкаський ОІПОПП, 2014 - 92 с. 3. Захарова Н.М. Популяризація здорового способу життя серед учнівської молоді: [навч посіб.] / Н. М. Захарова, О. І. Гуренко. - Донецьк : ЛАНДОНXXI, 2011-214 с. 4. Статут Всесвітньої організації охорони здоров'я. [Електронний pecypc]. - Режим доступу : http://zakon4.rada.gov.ua/ laws/show/995_599. - Заголовок 3 екрану

УДК 37.018.43(072)

Світлана Сьома

\section{ВИКОРИСТАННЯ ДИСТАНЦЙНИХ ФОРМ НАВЧАННЯ В НАУКОВИХ СЕКЦІЯХ МАЛОЇ АКАДЕМІЇ НАУК УКРАЇНИ}

Сьома С. О. Використання дистанційних форм навчання в наукових секціях Малої академії наук України.

У статті розглянуто проблему використання дистанційних форм навчання в освітньо-виховному процесі наукових секцій Малої академії наук України. Висвітлено досвід організації комбінованого дистанційного навчання в наукових секціях хіміко-біологічного відділення Сумського територіального відділення МАН України.

Ключові слова: Мала академія наук України, позашкільна освіта, дистанційна форма навчання.

Сёма С. А. Использование дистанционных форм обучения в научных секциях Малой академии наук Украины.

В статье рассматривается проблема использования дистанционных форм обучения в образовательном процессе научных секций Малой академии наук Украины. Представлен опыт организации комбинированного дистанционного обучения в научных секциях химико-биологического отделения Сумского территориального отделения МАН Украины.

Ключевые слова: Малая академия наук Украины, внешкольное образование, дистанционная форма обучения.

Syoma S. A. The use of distance learning in academic sections of the Minor Academy of Sciences of Ukraine.

The article is devoted to the problem of the use of distance learning in the educational process of scientific sections of the Minor Academy of Sciences of Ukraine. The author describes an experience of the combined distance learning in the scientific sections of chemical and biological department in the Sumy branch of Minor Academy of Science of Ukraine.

Key words: Minor Academy of Sciences of Ukraine, out-of-school education, distance learning.

Демократичні зміни в суспільстві визначили принципово нові пріоритети розвитку системи освіти. У сучасних соціокультурних умовах особливого значення та актуальності набуває підтримка обдарованої учнівської молоді, розвиток їі творчого потенціалу, розроблення нових стратегій навчання i виховання обдарованої 